\title{
ISOLASI Rhizopus oligosporus PADA BEBERAPA INOKULUM TEMPE DI KABUPATEN BANYUMAS
}

\author{
Ratna Stia Dewi dan Saefuddin 'Aziz \\ Fakultas Biologi Universitas Jenderal Soedirman, \\ Jl. Dr. Soeparno no.63 Karangwangkal Purwokerto \\ email: ratna_stiadewi@yahoo.co.id
}

\begin{abstract}
ABSTRAK
Tempe merupakan makanan tradisional asli Indonesia. Tempe mengandung gizi yang cukup tinggi, mencakup 25\% protein, 5\% lemak, $4 \%$ karbohidrat serta kaya akan mineral dan vitamin B12. Sentra produksi tempe di Indonesia paling banyak di temui di Jawa Tengah, dan salah satunya ada di Kabupaten Banyumas. Tekstur tempe yang kompak dan berwarna putih tercipta dari hasil kerja jamur genus Rhizopus, yang ditambahkan sebagai inokulum pada saat pembuatan tempe. Salah satu jenis jamur yang sering dijumpai dalam ragi tempe adalah Rhizopus oligosporus. Penelitian ini bertujuan untuk mengisolasi jamur $R$. oligosporus dari beberapa inokulum tempe di Kabupaten Banyumas.

56 jamur diisolasi dari inokulum tempe. Semua isolat termasuk dalam genera Rhizopus. 19 diantaranya dipilih berdasarkan warna konidia, yang terdiri dari isolat dengan konidia coklat keabu-abuan, dan abu-abu. Pengamatan makroskopik dan mikroskopik menunjukkan bahwa isolat terpilih adalah $R$. oligosporus.
\end{abstract}

Kata kunci : inokulum tempe Banyumas, isolasi, R.oligosporus

\section{ISOLATION OF Rhizopus oligosporus ON SOME BANYUMAS'S TEMPE INOCULUM}

\begin{abstract}
Tempe is a traditional food native to Indonesia. Tempe contain high nutrients, includes $25 \%$ protein, $5 \%$ fat, $4 \%$ carbohydrate and rich in minerals and vitamin B12. Banyumas is one of Tempe production centers in Central Java, Indonesia. The texture of tempeh is compact and white created by the labor of the fungus Rhizopus genus, which was added as inoculum at the time of making tempeh. One type of fungus that often is found in ragi tempeh Rhizopus oligosporus. This study aimed to isolate the fungus $R$. oligosporus of some tempe inoculum in Banyumas.

56 fungus were isolated from tempe inoculums. All isolates were belong to genera of Rhizopus. 19 of them were selected based on their conidia, which was consisted of greyish brown conidia, and grey conidia isolates. Macroscopic and microscopic observation showed that the selected isolates were $R$. oligosporus.
\end{abstract}

Keyword : Banyumas's inoculum tempe, isolation, R.oligosporus 


\section{PENDAHULUAN}

Tempe merupakan makanan tradisional khas Indonesia yang berpotensi sebagai makanan fungsional karena mempunyai gizi tinggi yang diperlukan oleh tubuh. Beberapa khasiat tempe bagi kesehatan antara lain memberikan

hipokolesterolemik, pengaruh antidiare, antioksidan, meningkatkan penyerapan kalsium dan zat besi, sebagai senyawa antitrombotik, menurunkan kolesterol dan sebagainya (Cahyadi, 2007). Menurut SNI No. 01-3144-1992 tempe adalah produk makanan hasil fermentasi biji kedelai oleh kapang tertentu, berbentuk padatan kompak dan berbau khas serta berwarna putih atau sedikit keabu-abuan. Pembuatan Tempe dilakukan dengan proses fermentasi, yaitu dengan menumbuhkan kapang Rhizopus spp. pada kedelai matang yang telah dilepaskan kulit epidermisnya (Haryoko dan Nova, 2009).

Tempe mengandung berbagai nutrisi yang diperlukan oleh tubuh seperti protein, lemak, karbohidrat, dan mineral. Tempe mengandung gizi yang cukup tinggi, mencakup $25 \%$ protein, 5\% lemak, 4\% karbohidrat serta kaya akan mineral dan vitamin B12. Beberapa penelitian menunjukkan bahwa zat gizi tempe lebih mudah dicerna, diserap, dan dimanfaatkan oleh tubuh dibandingkan dengan zat gizi kedelai yang dikonsumsi secara langsung (Dwinaningsih, 2010). Hal ini dikarenakan pada fermentasi tempe terjadi proses penguraian zat-zat makro molekul (seperti karbohidrat, protein dan lemak) dalam kedelai oleh aktivitas enzim-enzim jamur sehingga menghasilkan senyawa yang lebih sederhana dan lebih mudah dimanfaatkan oleh tubuh (Koswara, 1992).

Tempe tergolong produk fermentasi kedelai yang keberhasilannya ditentukan oleh interaksi kegiatan mikroorganisme dan lingkungannya.
Proses fermentasi menyebabkan terdegradasinya protein menjadi senyawa-senyawa dengan berat molekul yang lebih sederhana. Proses degradasi senyawa-senyawa yang terdapat dalam kotiledon kedelai pada saat fermentasi menyebabkan tempe mempunyai flavor yang spesifik.

Produk fermentasi dari bahan baku yang umumnya kedelai ini, mudah ditemui di kota maupun di desa dengan harga relatif murah. Sentra produksi tempe di Indonesia paling banyak di temui di Jawa Tengah, dan salah satunya ada di Kabupaten Banyumas. Usaha tempe banyak dilakukan oleh masyarakat pedesaan yang tergabung dalam kelompok-kelompok pengrajin tempe. Tekstur tempe yang kompak dan berwarna putih tercipta dari hasil kerja jamur, yang ditambahkan sebagai inokulum pada saat pembuatan tempe.

Kelompok jamur yang paling berperan dalam pembuatan tempe adalah genus Rhizopus. Jamur Rhizopus sp telah diketahui sejak lama sebagai jamur yang memegang peranan utama pada proses fermentasi kedelai menjadi tempe. Jamur Rhizopus sp akan membentuk padatan kompak berwarna putih yang disebut sebagai benang halus/biomasa. Benang halus/biomasa disebabkan adanya miselia jamur yang tumbuh pada permukaan biji kedelai dan menghubungkan biji-biji kedelai tersebut. Jenis Rhizopus sp sangat beragam sehingga perlu diisolasi serta diidentifikasi morfologi dan sifatsifatnya. Identifikasi berdasarkan morfologi jamur yaitu dengan mengamati sporangiofor, sporangium dan sporangiospora.

Masyarakat umumnya menyebut inokulum jamur untuk membuat tempe dengan laru atau ragi tempe. Jenis Rhizopus yang dapat digunakan sebagai inokulum dalam pembuatan tempe yaitu $R$. oligosporus, $R$. oryzae, $R$. stolonifer 
dan kombinasi dua jenis atau ketigatiganya (Kusuma, 2005).

Salah satu jenis jamur yang sering dijumpai dalam ragi tempe adalah Rhizopus oligosporus. Jamur ini dapat digunakan sebagai kultur tunggal dalam laru. Jenis jamur lainnya seperti Rhizopus oryzae, $R$. stolonifer dan $R$. arrhizus juga sering ditemui pada kultur campuran ragi tempe (Iskandar, 2002).

$R$. oligosporus dimanfaatkan dalam pembuatan tempe dari proses fermentasi kacang kedelai, karena $R$. oligosporus yang menghasilkan enzim fitase yang memecah fitat membuat komponen makro pada kedelai dipecah menjadi komponen mikro sehingga tempe lebih mudah dicerna dan zat gizinya lebih mudah terserap tubuh (Jennessen et al., 2008).

$R$. oligosporus dapat tumbuh optimum pada suhu $30-35^{\circ} \mathrm{C}$, dengan suhu minimum $12{ }^{\circ} \mathrm{C}$, dan suhu maksimum $\quad 42{ }^{\circ} \mathrm{C}$. Pertumbuhan $R$. oligosporus mempunyai ciri-ciri koloni abu-abu kecoklatan dengan tinggi $1 \mathrm{~mm}$ atau lebih. Sporangiofor tunggal atau dalam kelompok dengan dinding halus atau agak sedikit kasar, dengan panjang lebih dari $1000 \mu \mathrm{m}$ dan diameter 10-18 $\mu \mathrm{m}$. Sporangia globosa yang pada saat masak berwarna hitam kecoklatan, dengan diameter 100-180 $\mu \mathrm{m}$. Klamidospora banyak, tunggal atau rantaian pendek, tidak berwarna, dengan berisi granula, terbentuk pada hifa, sporangiofor dan sporangia. Bentuk klamidospora globosa, elip atau silindris dengan ukuran 7-30 $\mu \mathrm{m}$ atau 12-45 $\mu \mathrm{m} \mathrm{x}$ 7-35 $\mu \mathrm{m}$ (Madigan dan Martinko, 2006).

Dalam proses fermentasi kedelai menjadi tempe, inokulum memegang peranan yang sangat penting. Inokulum merupakan kumpulan spora Rhizopus. Inokulum memegang peranan penting dalam proses fermentasi pembuatan tempe, karena dapat mempengaruhi mutu tempe yang dihasilkan (Koswara, 1997;
Mulyati et al., 2002). Pengrajin tempe di Indonesia pada umumnya tidak menggunakan inokulum berupa biakan murni Rhizopus, tetapi sebagian besar menggunakan inokulum tempe berupa bubuk kering sebagai pembawa spora Rhizopus yang disebut dengan ragi. Sebagian pengrajin tempe lainnya menggunakan inokulum dari daun pembungkus tempe yang disebut dengan usar (Zakiatulyaqin, 1999).

Secara tradisional, Rhizopus untuk inokulum biasanya diambil dari daun bekas pembungkus tempe, yang dikenal dengan sebutan "usar". Namun demikian, penggunaan usar ini sangat terbatas dan hanya untuk produksi skala kecil (Rochintaniawati, 2011). Daun pembungkus tempe yang biasa digunakan sebagai usar yaitu daun waru (Hibiscus tilacius), daun jati (Tectona grandis), atau daun pisang (Musa paradiciaca) (Mulyati et al., 2002). Usar dibuat dengan membiarkan spora Rhizopus dari udara tumbuh pada kedelai matang yang ditaruh diantara dua lapis daun, permukaan bagian bawah kedua daun tersebut memiliki rambut-rambut halus (trikoma) di mana spora dan miselium kapang dapat melekat (Koswara, 1997). Setelah terjadi pertumbuhan maka Rhizopus sp. pada tahap selanjutya akan membentuk spora yang berfungsi sebagai benih untuk berkembangbiak, setelah tahap ini usar siap dijadikan sebagai pembungkus tempe.

Seiring dengan perkembangan ilmu pengetahuan, kini para pengrajin tempe banyak menggunakan inokulum bubuk sebagai pengganti usar yaitu ragi (Mulyati, 2001). Para pengrajin tempe membuat ragi dengan menggunakan tempe yang sudah jadi. Tempe tersebut di iris-iris tipis, dikeringkan, digiling menjadi bubuk halus dan hasilnya digunakan sebagai bahan inokulum dalam proses fermentasi. Beberapa daerah lainnya menggunakan miselium kapang yang tumbuh di permukaan 
tempe. Miselium yang tumbuh dipermukaan tempe diambil dengan cara rnengiris permukaan tempe tersebut, kemudian irisan permukaan yang diperoleh dijemur, digiling dan digunakan sebagai ragi (Mutiara, 2010).

Menurut Kusuma (2005) setiap tipe inokulum akan memberikan karakteristik tempe yang berbeda baik tekstur, warna dan kandungan nutrisinya. Tekstur, aroma dan kandungan nutrisi tempe sangat dipengaruhi oleh pembentukan miselium yang dihasilkan oleh Rhizopus sp. (Karsono et al., 2009). Tempe yang selama ini beredar di pasaran masih dibuat melalui proses fermentasi dengan menggunakan inokulum yang dapat diperoleh di pasar. Inokulum ini dibuat secara tradisional sehingga kemurnian dan komposisi kultur yang dihasilkan tidak konsisten dan tempe yang dihasilkanpun memiliki mutu organoleptik yang tidak seragam.

Kurang konsistennya kultur ini akan sangat menghambat komersialisasi tempe karena produk yang diproduksi pada skala komersial/skala besar diharapkan memiliki mutu organoleptik terutama rasa, aroma, dan penampakan tempe yang konsisten dan seragam (Karsono et al., 2009). Beragamnya sumber ragi tempe mempengaruhi kualitas tempe yang dihasilkan. Ragi yang baik sangat penting untuk menghasilkan tempe dengan mutu yang baik. Berbagai penelitian diperlukan sebagai upaya untuk peningkatan kualitas ragi tempe. Diantara ratusan jenis $R$. oligosporus yang ada di Indonesia, hanya sedikit yang telah digali potensinya menjadi inokulum produk fermentasi seperti tempe. $R$. oligosporus yang diisolasi dari berbagai inokulum tempe di Kabupaten Banyumas belum diketahui. Oleh karena itu dalam upaya perbaikan mutu tempe sangat diperlukan penelitian untuk menemukan isolat jamur $R$. oligosporus dari beberapa inokulum yang ada di Kabupaten Banyumas.
Penelitian ini nantinya akan dilanjutkan dengan menguji potensi keunggulanya dalam dapat mempertahan kualitas tempe yang dihasilkan yang pada akhirnya berdampak pada peningkatan ekonomi masyarakat desa. Penelitian ini bertujuan untuk mengisolasi jamur $R$. oligosporus dari beberapa inokulum tempe di Kabupaten Banyumas.

\section{METODE PENELITIAN}

\section{Alat dan Bahan}

Alat-alat yang digunakan dalam penelitian ini yaitu alat kerja mikrobiologis, antara lain: peralatan gelas, autoklaf, laminar air flow, mikroskop, magnetic stirrer, oven, refrigerator dan timbangan analitik.

Bahan-bahan yang digunakan dalam penelitian ini yaitu media pertumbuhan untuk isolasi R.oligosporus adalah medium Potato Dextrose Agar (PDA), media untuk identifikasi yang meliputi Czapek Yeast Extract Agar (CYA), 25\% Glycerol Nitrate Agar (G25N), dan Malt Extract Agar (MEA). Komposisi medium Czapek Yeast Extract Agar (CYA) per $1000 \mathrm{ml}$ adalah 1,0 g $\mathrm{K}_{2} \mathrm{HPO}_{4}, 10 \mathrm{ml}$ czapek concentrate , 5,0 $\mathrm{g}$ yeast extract powder, $30 \mathrm{~g}$ sukrosa, 15 g agar. Sedangkan komposisi Czapek Concentrate dalam $100 \mathrm{ml}$ adalah $30 \mathrm{~g}$ $\mathrm{NaNO}_{3}, 5,0$ g KCl, 5,0 g $\mathrm{MgSO}_{4} 7 \mathrm{H}_{2} \mathrm{O}$, $0,1 \mathrm{~g} \mathrm{FeSO}_{4} .7 \mathrm{H}_{2} \mathrm{O}$. Komposisi medium $25 \%$ Glycerol Nitrate Agar (G25N) per $1000 \mathrm{ml}$ adalah $0,75 \mathrm{~g} \mathrm{~K}_{2} \mathrm{HPO}_{4}, 7,5 \mathrm{ml}$ czapek concentrate, 3,7 g yeast extract powder, $250 \mathrm{~g}$ glycerol, $12 \mathrm{~g}$ agar. Sumber isolat yang digunakan dalam penelitian ini adalah ragi tempe dari industri tempe di Kabupaten Banyumas, usar daun waru, usar daun jati dan usar daun pisang.

\section{Prosedur Penelitian}

Penelitian ini dilakukan dari April 2011 sampai dengan Juli 2011 di 
Laboratorium Mikologi dan Fitopatologi Fakultas Biologi Universitas Jenderal Soedirman Purwokerto $R$. oligosporus diperoleh dari hasil isolasi beberapa inokulum tempe berupa ragi tempe, usar daun waru, dan usar daun jati.

Penelitian ini menggunakan metode survei dengan pendekatan deskriptif. Terdapat 4 desa dalam penentuan daerah di Kabupaten Banyumas yang digunakan sebagai sumber pengumpulan sampel inokulum tempe yaitu Desa Pliken, Desa Rawalo, Desa Tamansari dan Desa Karanggude yang menjadi sentra produksi tempe di Kabupaten Banyumas dan dijadikan sebagai tempat pengambilan sampel.

Semua medium yang digunakan (PDA, CYA, G25N, dan MEA) disterilkan pada suhu $121{ }^{\circ} \mathrm{C}$ dengan tekanan 2 atm selama 20 menit. Isolat jamur yang diperoleh dari koloni jamur di medium PDA dipindah dan disimpan pada medium miring PDA sebelum diidentifikasi lebih lanjut.

Pelaksanaan Penelitian terdiri dari 2 tahap, yaitu isolasi Rhizopus spp dan identifikasi $R$. oligosporus. Tahapan isolasi Rhizopus spp dari ragi tempe dilakukan dengan menebar ragi pada medium PDA secara aseptis kemudian diinkubasi selama $5 \times 24$ jam. Isolasi Rhizopus spp dari usar daun waru, daun jati dan daun pisang pembungkus dilakukan dengan memotong daun berukuran $2 \times 2 \mathrm{~cm}$ secara aseptis kemudian di inokulasikan pada medium PDA dan di inkubasi selama 5x24 jam. Pemindahan isolat (pemurnian) diulang sebanyak 4 kali sampai isolat benar-benar murni, kemudian isolat yang sudah benar-benar murni disimpan pada PDA miring.

\footnotetext{
Tahapan
oligosporus diawali dentifikasi meremajakan isolat jamur pada medium PDA miring yang telah dikelompok sesuai tempat asal inokulum, kemudian dikarakterisasi berdasarkan pengamatan
}

morfologi makroskopis dan pengamatan morfologi mikroskopis.

Identifikas dibatasi pada isolat dengan warna konidia keabu-abuan kecoklatan menggunakan medium CYA, G25N, MEA yang diinkubasi selama 7 hari (Pitt dan Hocking, 1985).

Pengamatan morfologi makroskopis (morfologi koloni) meliputi bentuk koloni, warna koloni, warna sebalik koloni (reverse side), ada tidaknya tetes eksudat, garis radial, garis kosentris dan karakter khusus yang dimiliki. Pengamatan morfologi mikroskopis (morfologi sel) meliputi ada tidaknya septat pada hifa, warna hifa, ukuran hifa, percabangan hifa, struktur reproduksi (bentuk spora, warna spora, permukaan spora dan ukuran spora) tangkai penghasil spora atau sporangiofor (warna, percabangan, permukaan dan ukuran sporangiofor) menggunakan mikroskop (Alexopolous et al., 1996).

\section{HASIL DAN PEMBAHASAN}

Dari tahapan isolasi Rhizopus spp pada beberapa inokulum tempe diperoleh 56 isolat. Isolat-isolat yang diperoleh dari hasil isolasi dikarakterisasi dan kemudian diidentifikasi. Karakterisasi isolat meliputi pengamatan morfologi makroskopis, dan mikroskopis.

Pengamatan

morfologi makroskopis menunjukkan bahwa 19 isolat diantara 56 isolat mempunyai warna koloni yang menyerupai warna koloni jamur $R$. oligosporus dan $R$. oryzae. Samson et al. (1995) menyatakan bahwa jamur $R$. oligosporus dan $R$. oryzae memiliki warna abu-abu (kecoklatan). Dari ke-59 isolat diseleksi 19 isolat yang memiliki warna abu-abu, abu-abu kecoklatan, dan coklat untuk dilakukan identifikasi lebih lanjut sampai tingkat spesies untuk memperoleh isolat $R$. oligosporus. Ke-19 isolat yang dipilih berdasarkan warna koloni yang 
ditumbuhkan pada medium PDA ditampilkan pada Tabel 1.

Tabel 1. Warna koloni isolat pada medium PDA.

\begin{tabular}{|c|c|c|c|}
\hline No. isolat & Kode isolat & Asal & Warna koloni \\
\hline 1. & DW1(1) & Usar Daun Waru & abu-abu kecoklatan \\
\hline 2. & RRP2B1 (2) & Ragi Merk $\mathrm{R}_{1}$ & abu-abu \\
\hline 3. & RB1 (3) & Ragi Merk $B_{1}$ & abu-abu \\
\hline 4. & RRP2B1 (4) & Ragi Merk R & abu-abu \\
\hline 5. & RRP2B2 (5) & Ragi Merk $\mathrm{R}_{2 \mathrm{~B}}$ & abu-abu \\
\hline 6. & DW1 A2 (6) & Usar Daun Waru $1 \mathrm{~A}$ & abu-abu kecoklatan \\
\hline 7. & DJ1 1A (7) & Usar Daun Jati ${ }_{1 \mathrm{~A}}$ & abu-abu \\
\hline 8. & 8 (RB2) (8) & Ragi Merk $B_{2-8}$ & Coklat \\
\hline 9. & RRP2B2 (9) & Ragi Merk $B_{2-10}$ & abu-abu \\
\hline 10. & DJ (10) & Usar Daun Jati ${ }_{1 \mathrm{~B}}$ & abu-abu \\
\hline 11. & RRP2A (11) & Ragi Merk R2A & abu-abu \\
\hline 12. & $\mathrm{RB}(12)$ & Ragi Merk B & Coklat \\
\hline 13. & DW1 (13) & Usar Daun Waru $_{1}$ & abu-abu kecoklatan \\
\hline 14. & DW1 1 (14) & Usar Daun Waru $_{1-1}$ & abu-abu \\
\hline 15. & DW3A1 (15) & Usar Daun Waru 3 & abu-abu \\
\hline 16. & DP1 (16) & Usar Daun Pisang $_{1}$ & abu-abu kecoklatan \\
\hline 17. & RRP1 (17) & Ragi Merk R $\mathrm{R}_{1-1}$ & abu-abu \\
\hline 18. & DW2 A (18) & Usar Daun Waru $2 \mathrm{~A}$ & abu-abu \\
\hline 19. & DP1B (19) & Usar Daun Pisang $_{1 \mathrm{~B}}$ & abu-abu \\
\hline
\end{tabular}

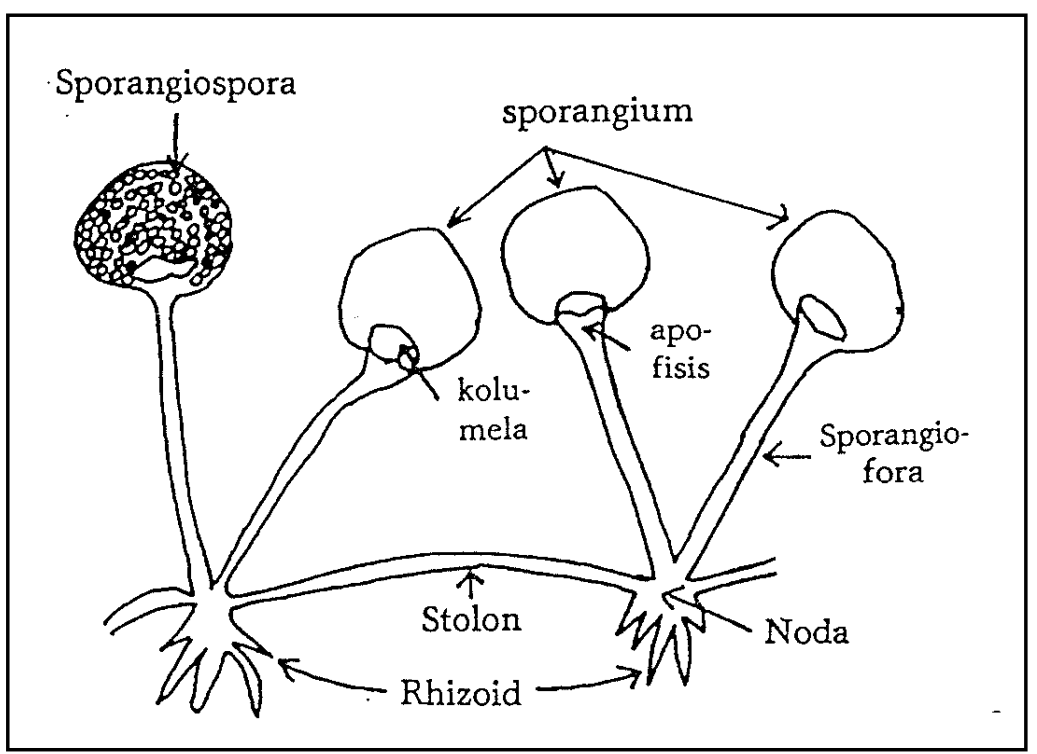

Gambar 1. Bentuk Morfologi Jamur Rhizopus (Fardiaz, 1989)

Semua isolat yang dipilih memiliki karakter pembeda secara makroskopis dan mikroskopis.
Pengamatan secara makroskopis menunjukkan ke-19 isolat tersebut memiliki warna koloni abu-abu 
(kecoklatan), pertumbuhannya cepat, dan membentuk miselium seperti kapas. Pengamatan secara mikroskopis ke-19 isolat terlihat adanya rhizoid, stolon, sporangia pada ujung sporangiofora dan tidak bersepta. Hal ini menunjukkan bahwa ke-19 isolat genera Rhizopus. Menurut Fardiaz (1989) jamur Rhizopus memiliki ciri-ciri sebagai berikut; hifa nonseptat, mempunyai stolon dan rhizoid yang warnanya gelap jika sudah tua, sporangiofora tumbuh pada noda dimana terbentuk juga rhizoid, sporangia biasanya besar dan berwarna hitam, kolumela agak bulat dan apofisis berbentuk seperti cangkir, membentuk hifa negatif yang melakukan penetrasi pada subtrat dan hifa fertil yang memproduksi sporangia pada ujung sporangiofora, pertumbuhannya cepat, dan membentuk miselium seperti kapas (Gambar 1).

Ke-19 isolat genera Rhizopus kemudian dilakukan pengamatan dalam medium identifikasi yaitu medium CYA, G25N, MEA untuk menentukan spesiesnya. Ke-19 isolat tersebut dikelompokkan sesuai warna konidia, warna miselia. bentuk konidia yaitu oval, globosa, bentuk klamidospora yaitu globosa, elip atau silindris, bentuk sporangiofor yaitu tunggal atau dalam bentuk kelompok, panjang dan diameter sporangiosfor, diameter sporangium.

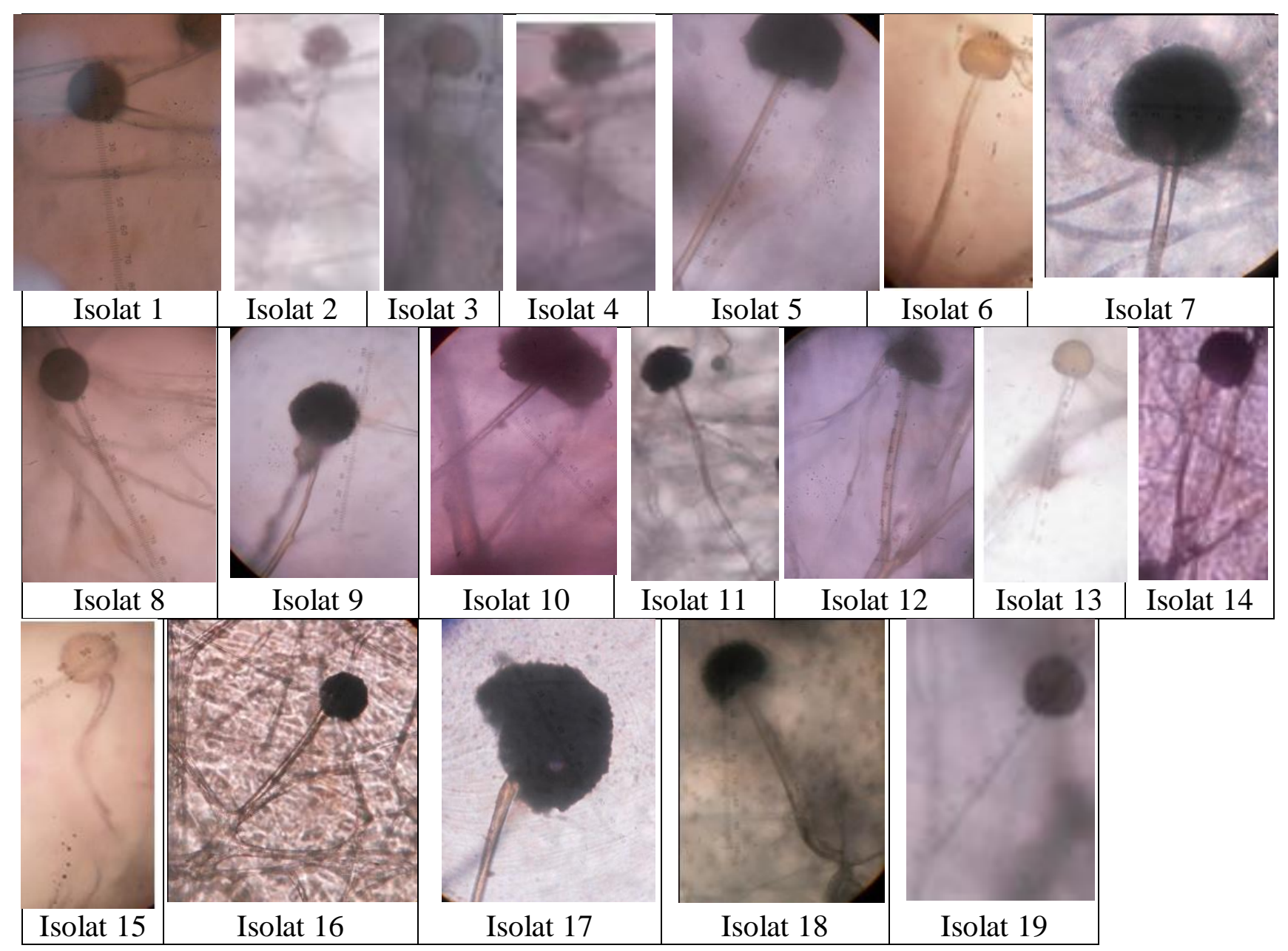

Gambar 2. Pengamatan mikroskopis 
Tabel 2. Pengamatan makroskopik dan mikroskopik ke-19 isolat hasil isolasi beberapa inokulum tempe

\begin{tabular}{|c|c|c|c|c|c|c|c|c|c|c|c|c|c|c|c|c|c|c|c|c|}
\hline \multirow[t]{2}{*}{ Karakter } & \multicolumn{19}{|c|}{ No isolat } & \multirow[t]{2}{*}{ R. oligosporus } \\
\hline & 1 & 2 & 3 & 4 & 5 & 6 & 7 & 8 & 9 & 10 & 11 & 12 & 13 & 14 & 15 & 16 & 17 & 18 & 19 & \\
\hline $\begin{array}{c}\text { Warna } \\
\text { Sporangiospora }\end{array}$ & $\mathrm{Hc}$ & $\mathrm{Hc}$ & $\mathrm{Hc}$ & $\mathrm{Hc}$ & $\mathrm{Hc}$ & $\mathrm{Hc}$ & $\mathrm{Hc}$ & $\mathrm{Hc}$ & $\mathrm{Hc}$ & $\mathrm{Hc}$ & $\mathrm{Hc}$ & $\mathrm{Hc}$ & $\mathrm{Hc}$ & $\mathrm{Hc}$ & $\mathrm{Hc}$ & $\mathrm{Hc}$ & $\mathrm{Hc}$ & $\mathrm{Hc}$ & $\mathrm{Hc}$ & $\begin{array}{c}\text { Hitam } \\
\text { kecoklatan* }\end{array}$ \\
\hline Warna miselium & $\mathrm{P}$ & $\mathrm{P}$ & $\mathrm{P}$ & $\mathrm{P}$ & $\mathrm{P}$ & $\mathrm{P}$ & $\mathrm{P}$ & $\mathrm{P}$ & $\mathrm{P}$ & $\mathrm{P}$ & $\mathrm{P}$ & $\mathrm{P}$ & $\mathrm{P}$ & $\mathrm{P}$ & $\mathrm{P}$ & $\mathrm{P}$ & $\mathrm{P}$ & $\mathrm{P}$ & $\mathrm{P}$ & Putih * \\
\hline Panjang & 15 & 15 & 15 & 40 & 15 & 12 & 40 & 20 & 17 & 12 & 16 & 25 & 25 & 20 & 23 & 25 & 35 & 17 & 17 & $150-400 \mu \mathrm{m} *$ \\
\hline $\begin{array}{l}\text { sporangiosfor } \\
(\mu \mathrm{m})\end{array}$ & 5 & 0 & 0 & 0 & 0 & 5 & 0 & 0 & 2,5 & 5 & 0 & 0 & 0 & 0 & 7,5 & 0 & 0 & 5 & 5 & \\
\hline $\begin{array}{c}\text { Panjang } \\
\text { sporangium }(\mu \mathrm{m})\end{array}$ & $\begin{array}{c}82 \\
5\end{array}$ & 80 & $\begin{array}{c}87 \\
5\end{array}$ & $\begin{array}{c}82 \\
5\end{array}$ & $\begin{array}{c}92 \\
5\end{array}$ & $\begin{array}{c}87 \\
5\end{array}$ & $\begin{array}{c}12 \\
0\end{array}$ & $\begin{array}{c}87 \\
5\end{array}$ & 85 & $\begin{array}{c}82 \\
5\end{array}$ & $\begin{array}{c}87 \\
5\end{array}$ & $\begin{array}{c}87 \\
5\end{array}$ & 85 & $\begin{array}{c}87 \\
5\end{array}$ & $\begin{array}{c}82 \\
5\end{array}$ & $\begin{array}{c}87 \\
5\end{array}$ & $\begin{array}{c}82 \\
5\end{array}$ & $\begin{array}{c}87 \\
5\end{array}$ & 80 & $80-120 \mu \mathrm{m} *$ \\
\hline $\begin{array}{c}\text { Tekstur } \\
\text { sporangiosfor }\end{array}$ & $\mathrm{H}$ & $\mathrm{H}$ & $\mathrm{H}$ & $\mathrm{H}$ & $\mathrm{H}$ & $\mathrm{H}$ & $\mathrm{H}$ & $\mathrm{H}$ & $\mathrm{H}$ & $\mathrm{H}$ & $\mathrm{H}$ & $\mathrm{H}$ & $\mathrm{H}$ & $\mathrm{H}$ & $\mathrm{H}$ & $\mathrm{H}$ & $\mathrm{H}$ & $\mathrm{H}$ & $\mathrm{H}$ & Halus $* *$ \\
\hline Bentuk kolumela & GS & GS & GS & GS & GS & GS & GS & GS & GS & GS & GS & GS & GS & GS & GS & GS & GS & GS & GS & $\begin{array}{l}\text { Globose } \\
\text { sampai sub } \\
\text { globose ** }\end{array}$ \\
\hline Bentuk konidia & GE & GE & GE & GE & GE & GE & GE & GE & GE & GE & GE & GE & GE & GE & GE & GE & GE & GE & GE & $\begin{array}{l}\text { Globose,ellips } \\
\text { oidal (oval) ** }\end{array}$ \\
\hline $\begin{array}{c}\text { Panjang } \\
\text { Sporangiospora } \\
(\mu \mathrm{m})\end{array}$ & 7,5 & 7,5 & 10 & 10 & 10 & 10 & 10 & 10 & 7,5 & 7,5 & 7,5 & 10 & 10 & 7,5 & 10 & 10 & 10 & 10 & 7,5 & $\underset{* *}{7-10(24) \mu \mathrm{m}}$ \\
\hline $\begin{array}{c}\text { Bentuk } \\
\text { klamidospora }\end{array}$ & $S$ & $\mathrm{~S}$ & $S$ & $\mathrm{~S}$ & $\mathrm{~S}$ & $\mathrm{~S}$ & $S$ & $S$ & $\mathrm{~S}$ & $S$ & $S$ & $S$ & $\mathrm{~S}$ & $S$ & $S$ & $S$ & $S$ & $S$ & $S$ & $\begin{array}{c}\text { Abundant, } \\
\text { single atau } \\
\text { rantai pendek }\end{array}$ \\
\hline $\begin{aligned} \text { terangan } & \\
= & \mathrm{H} \\
= & \mathrm{F}\end{aligned}$ & $\mathrm{m} k$ & & & & & $\begin{array}{l}= \\
=\end{array}$ & $\begin{array}{l}\text { lus } \\
\text { lobos }\end{array}$ & & & , & $S$ & & $\begin{array}{l}= \\
=\end{array}$ & $\begin{array}{l}\text { lobose } \\
\text { ngle }\end{array}$ & 111 & & & & & \\
\hline
\end{tabular}


Karakter hasil pengamatan mikroskopis ke-19 isolat tersebut dapat dilihat pada Tabel 2. Dari pengamatan mikroskopis pada Tabel 2 menunjukkan bahwa 19 isolat mempunyai panjang sporangiosfor $150-400 \mu \mathrm{m}$, sporangium 80-120 $\mu \mathrm{m}$ (Gambar 1). Atas dasar pengamatan morfologi tersebut, semua karakter yang dimiliki isolat jamur TPIK sesuai dengan karakter $R$. oligosporus yang dijelaskan oleh Pitt dan Hocking (1985) yaitu panjang sporangiosfor R. oligosporus $150-400 \mu \mathrm{m}$ lebih pendek dari R.oryzae yaitu lebih dari $1500 \mu \mathrm{m}$ sedangkan sporangium $R$. oligosporus 80-120 $\mu \mathrm{m}$ lebih pendek dari R.oryzae. Bentuk kolumela globose dengan ukuran panjang dan lebar yaitu $50 \mu \mathrm{m}$ dan $40 \mu \mathrm{m}$ juga menunjukkan bahwa semua isolat hasil isolasi beberapa inokulum tempe termasuk $R$. oligosporus. Berdasarkan hasil pengamatan secara makroskopik dan mikroskopik maka ke- 19 isolat jamur hasil isolasi beberapa inokulum tempe yang dipilih termasuk dalam $R$. oligosporus.

Berdasarkan karakter dari 19 isolat yang ditampilkan pada Tabel 2, menunjukkan bahwa 19 isolat hasil isolasi dari beberapa inokulum tempe termasuk anggota spesies R.oligosporus karena memiliki karakter spesifik yang sesuai dengan karakter R. oligosporus. Pitt dan Hocking (1997), serta Samson et al., (1995) menyatakan bahwa karakter dari R.oligosporus adalah warna sporangiospora hitam kecoklatan, warna miselium putih, panjang sporangiosfor $150-400 \mu \mathrm{m}$, panjang sporangium 80-120 $\mu \mathrm{m}$, tekstur sporangiosfor halus, bentuk kolumela globose sampai sub globose, bentuk konidia globose atau ellipsoidal (oval), panjang sporangiospora 7-10 $\mu \mathrm{m}$, serta bentuk klamidospora abundant, single atau rantai pendek. Hasil ini hampir sama dengan hasil penelitian yang dilakukan oleh Wipradnyadewi et al. (2004). Berdasarkan pengamatan morfologi makroskopik dan mikroskopik telah diperoleh 7 isolat diidentifikasi sebagai R.oligosporus dari 70 isolat jamur berkonidia abu-abu kecoklatan yang berhasil diisolasi dari 7 sampel inokulum tempe di Yogyakarta (beberapa merk tempe dan tempe tanpa merk yang dibungkus dengan daun pisang, ragi tempe yang dibeli di pasar Demangan, dan usar daun waru). Ke-7 isolat hasil isolasi sesuai dengan karakter $R$. oligosporus yang dijelaskan oleh Pitt dan Hocking (1997), serta Samson et al. (1995).

Isolat lain diantara 56 isolat yang berhasil diisolasi (selain ke-19 isolat tersebut) semuanya termasuk genus Rhyzopus (data tidak ditampilkan). Semua isolat memiliki ciri hifa nonseptat, mempunyai stolon dan rhizoid yang warnanya gelap jika sudah tua, sporangiofora tumbuh pada noda dimana terbentuk juga rhizoid, sporangia besar dan berwarna hitam, kolumela agak bulat dan apofisis berbentuk seperti cangkir, memproduksi sporangia pada ujung sporangiofora, pertumbuhannya cepat, dan membentuk miselium seperti kapas seperti pendapat Fardiaz (1989).

Tabel 3. Hasil isolasi dan identifikasi Rhizopus spp. dari berbagai asal isolat (Olivia et al.,1998)

\begin{tabular}{ll}
\hline Asal isolat & Spesies Rhizopus \\
\hline Daun waru & $R$. arrhizus, $R$. oryzae \\
Laru tempe bekasi & $R$. arrhizus, $R$. oligosporus, $R$. oryzae \\
Laru tempe bumiayu & $R$. oligosporus \\
Laru tempe LIPI & $R$. oligosporus \\
Tempe malang & $R$. oligosporus \\
\hline
\end{tabular}


Menurut Hayati (2009), beberapa jenis Rhizopus yang berperan penting dalam pembuatan tempe adalah $R$. oligosporus dan $R$. orizae, sedangkan jenis Rhizopus lain yang juga terdapat adalah $R$. stolonifer dan $R$. arrhizus. Berdasarkan hasil penelitian yang dilakukan oleh Hesseltine (1965), dalam pembuatan tempe melibatkan sejumlah Rhizopus dan strainnya disebutkan bahwa 40 strain yang termasuk ke dalam 6 spesies yang diperoleh selama pembuatan tempe. Keenam spesies itu adalah $R$. oligosporus, $R$. stolonifer, $R$. oryzae, $R$. formosaensis, dan $R$. achlamydosporus. Sedangkan Olivia et al. (1998) menyebutkan dalam penelitiannya bahwa Rhizopus yang diisolasi dari daun waru (Hibiscus tiliaceus Linn), laru tempe Bekasi, Bumiayu dan LIPI, dan tempe Malang, adalah 6 spesies $R$. arrhizus Fischer (5 isolat), $R$. oligosporus Saito (4 isolat), dan $R$. oryzae Went \& $\mathrm{P}$. Geerlings (3 isolat) (Tabel 3).

\section{KESIMPULAN}

Lima puluh enam isolat jamur berhasil diisolasi dari 5 sampel inokulum tempe dan sebanyak 19 isolat termasuk dalam anggota R.oligosporus.

\section{DAFTAR PUSTAKA}

Alexopoulos, C. J., C. W. Mims and M. Blackwell, 1996, Introductory Mycology, John Wiley and Sons Inc., USA.

Cahyadi, W., 2007, Kedelai Khasiat dan Teknologi, Bumi Aksara, Jakarta.

Dwinaningsih, E. A., 2010, Karakteristik dan sensori tempe dengan variasi bahan baku kedelai/beras dan penambahan angka serta variasi lama fermentasi, Skripsi (tidak dipublikasikan), Fakultas Pertanian Universitas Sebelas Maret, Surakarta.

Fardiaz S., 1989, Mikrobiologi Pangan, PAU-IPB, Bogor.

Handajani, S., 2001, Indigenous mucuna tempe as functional food, Asia Pacific J. Clin. Nutr., Vol. 10, 222-225.

Haryoko, M. dan K. Nova, 2009, Pembuatan tempe saga (Adenanthera pavonia L) menggunakan ragi tepung tempe dan ragi instan, Laporan Penelitian (tidak dipublikasikan), Fakultas Teknik Universitas Diponegoro, Semarang.

Hayati, S., 2009, Pengaruh waktu fermentasi terhadap kualitas tempe dari biji nangka (Arthocarpus heterophyllus) Dan penentuan kadar zat gizinya, Skripsi (tidak dipublikasikan), Universitas Sumatera Utara, Medan.

Hesseltine, C. W., 1965, Studies on extracellulair proteolytic enzymes of Rhizopus oligosporus, Journal Microbiology II.

Hesseltine C. W., 1985, Genus Rhizopus and Tempeh Microorganisms: Asian Symposium on non -salted Soybean Fermentation, Tsukuba.

Iskandar, Y.M., 2002, Isoflavonoida Hasil Fermentasi Kedelai Menggunakan Inokulum Kultur Campuran, Prosiding Semnas XI, Jasakiai, Yogyakarta. 
Jennessen, J., J. Schnurer, J. Olsson, R.A. Samson, and J. Dijksterhuis, 2008, Morphological characteristics of sporangiospores of the tempe fungus Rhizopus oligosporus differentiate it from other taxa of the $R$. microsporus group. Mycol. Res, Vol.112, 547-63.

Karsono. Y, A. Tunggal, A. Wiratama, dan P. Adimulyo, 2009, Pengaruh jenis kultur strater terhadap mutu organoleptik tempe kedelai, Laporan Penelitian (tidak dipublikasikan), Departemen Ilmu dan Teknologi Pangan Institut Pertanian Bogor, Bogor.

Koswara, S., 1992, Daftar Komposisi Bahan Makanan, Penerbit Bharata, Jakarta.

Koswara, S,. 1997, Mengenal makanan tradisional, Prosiding Teknologi dan Industri Pangan, Vol.8, 7478.

Kusuma, Y. D., 2005, Kemampuan Rhizopus oligosporus pada fermentasi tempe kedelai sindoro americana dan campuran masing-masing kedelai dengan kecipir dalam menghasilkan isoflavon aglikon, Skripsi (tidak diublikasikan), Fakultas Biologi Universitas Jenderal Soedirman, Purwokerto.

Madigan, M.T., and J.M. Martinko, 2006, Brock Biology of Microorganisms 11th ed. Pearson Education, New Jersey.

Mulyati. Y. I, S.P. Raharti, dan A.B. Thelma A.B., 2002, Pembuatan Inokulum Menggunakan Isolat
Rizopus $\mathrm{C}_{1}$ dan Rhizopus $\mathrm{C}_{2}$ pada Subtrat Campuran, Prosiding Seminar Tantangan Penelitian Kimia, LIPI, Bandung.

Mutiara, A., 2010, Analisis pengaruh bahan baku, bahan bakar dan tenaga kerja terhadap produksi tempe di kota Semarang, Skripsi (tidak dipublikasikan), Fakultas Ekonomi, Universitas Diponegoro, Semarang.

Olivia, F., A. W. Gunawan., dan A. Suwanto., 1998, Isolasi dan Detekksi Lipase Rhizopus spp. (Isolation and Detection of Lipase from Rhizopus spp.), Catatan Penelitian. Hayati, Vol.5, No. 4, 113-115.

Pitt, J.I. and A.D Hocking, 1985, Fungi and Food Spoilage, Academic Press, Australia.

Rochintaniawati, D., 2011, Pembuatan Ragi Tempe, URL : http://file.upi.edu/Direktori/FPM IPA/JUR._PEND._BIOLOGI/DI ANA_ROCHINTANIAWATI/B IOLOGY_TERAPAN/PEMBU ATAN_RAGI_TEMPE_\%26_T EMPE.pdf, diakses 25 Juli 2011.

Samson, R.A., E.S. Hoekstra, J.C. Frisvad and O. Filtenborg, 1995, Introduction to Food-Borne Fungi, Baarn and Lyngby, Netherlands.

Wipradnyadewi, P.A.S., E.S. Rahayu, dan S. Raharjo, 2004, Isolasi dan Identifikasi Rhizopus oligosporus pada Beberapa Inokulum Tempe, Laporan penelitian Proyek Hibah Penelitian Tim Pascasarjana (HPTP) Angkatan I Tahun Ke-2, Fakultas Teknologi Pertanian, UGM. 
Molekul, Vol. 6. No. 2. Nopember, 2011: 93 - 104

Zakiatulyaqin, 1999, Potensi Rhizopus microspores v. Tiegh. UICC 520

dan UICC 521 dalam melakukan

fermentasi tempe an

biotransformasi isoflavon,

Skripsi (tidak dipublikasikan),

Program Studi Biologi

Universitas Indonesia, Depok. 